Jurnal al-Af'idah: Jurnal Pendidikan bahasa Arab Dan Pengajarannya. Volume I,Nomor I September 2017

\title{
LINGKUNGA BAHASA
}

SEBAGAI MEDIA PEMBELAJARAN BAHASA ARAB

(Ikhtiar membangun Pembelajaran Yang Efektif dan Produktif)

Oleh: Anwar Sadat, M. Pd.I

Anwar.sadat10@yahoo.co.id

\begin{abstract}
الملخصص
سوف تعليم اللغة وخاصة العربية تعمل بشكل جيد إذا كانت مدعومة من قبل بيئة جيدة. البيئة بمثابة وسيلة التعلم لغرض إصله

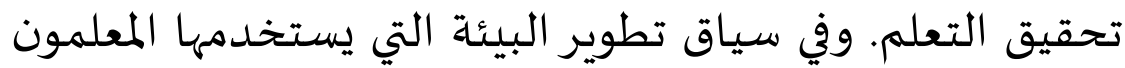

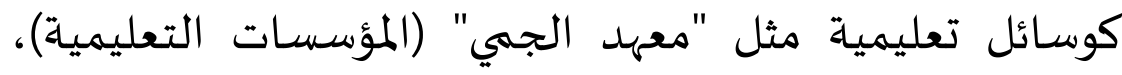
جمة اللوغه (يوم الجمعاة يتحدث العربية)، يستفيد المتعلمون

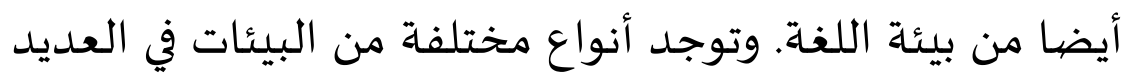

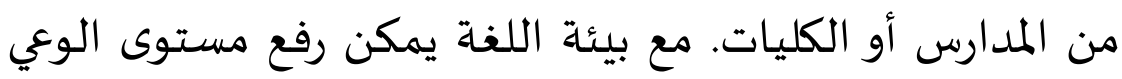

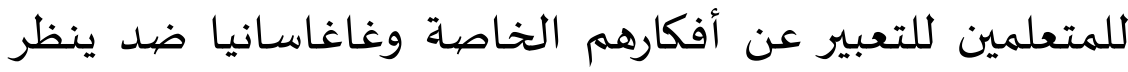
إلهها، سمعت وقراءةوبالتالي، فإن اللغة العربية وبيئة الوعي لها لهابها علاقة إيجابية مع اللغة العربية للطلاب أو الطلاب. يمكن وفراعلابه تقسيم البيئة العربية إلى بيئة رسمية وبيئة لغوية غير رسمية. البيئة اللغوية غير الرسمية هي البيئة التي تم إنشاؤها لدعم البيه

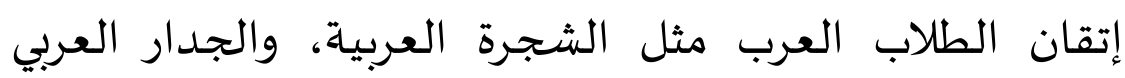

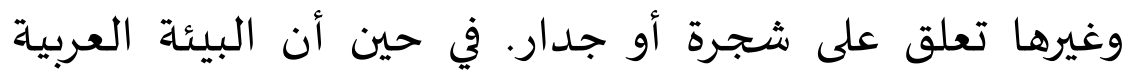
الرسمية هي بيئة عربية مبرمجة باستمرار من خلال الأنشطة في
\end{abstract}


Jurnal al-Af'idah: Jurnal Pendidikan bahasa Arab Dan Pengajarannya. Volume I,Nomor I September 2017

أيام معينة بتوجياه من معلم أو أستا مثل اللغة العربية، ماسكانول لوغا (كامبا) وغيرها.

وينبغي أن تراعي البيئة المصيممة مبادئ الكفاءة، واحتياجات

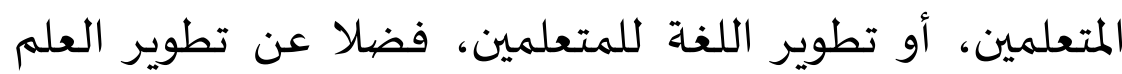

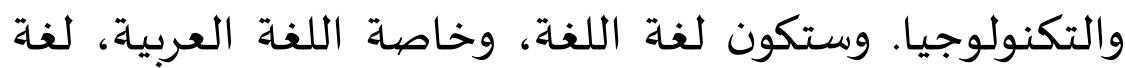
يمكن استخدامها من قبل الطلاب أو الطلاب إذا كانت اللغة وحابة

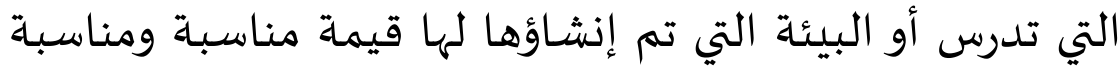
مع تطور العالم.

كلمات البحث: اللغة، البيئة، وسـائل تعليمية 
Jurnal al-Af'idah: Jurnal Pendidikan bahasa Arab Dan Pengajarannya. Volume I,Nomor I September 2017

\section{A. PENDAHULUAN}

Lingkungan bahasa sebagai media pembelajaran khususnya media pembelajaran bahasa Arab sangat banyak ragamnya antara lain media grafis, media audio, media proyeksi bahkan lingkungan sekitar kita disebut juga sebagai media. Seiring perkembangan zaman lingkungan banyak dimanfaatkan tenaga pengajar di Sekolah dan Perguruan tinggi secara khususnya sebagai media langsung, misalnya dibeberapa perguruan tinggi mendirikan ma'had al-jam'i (lembaga pendidikan) yang salah satu tujuannya adalah untuk menciptakan media pembelajaran bahasa yang alami supaya para mahasiswa dapat memiliki kemampuan bahasa secara alami.

Kata media berasal dari bahasa latin dan merupakan bentuk dari kata medium yang secara harfiah berarti perantara atau pengantar pesan dari pengirim ke penerima pesan. Adapun secara istilah atau istilahiy media adalah komponen sumber belajar atau sarana fisik yang mengandung materi instruksional di lingkungan peserta didik yang dapat merangsang peserta didik untuk belajar atau alat yang digunakan untuk menyampaikan atau mengantarkan pesan-pesan pembelajaran. ${ }^{1}$ Jadi, media sangat berperan penting untuk mengantar pesan ke penerima pesan agar pesan tersampaikan dengan baik.

Beragam media pendukung yang dapat digunakan oleh Dosen untuk menyampaikan pesan materi pelajaran melalui

${ }^{1}$ TejoNurseto, Membuat Media Pembelajaran yang Menarik, (UNY Jurnal Ekonomi \& Pendidikan, Volume 8 Nomor 1, April 2011, 21 
Jurnal al-Af'idah: Jurnal Pendidikan bahasa Arab Dan Pengajarannya. Volume I,Nomor I September 2017

penglihatan dan pendengaran peserta didik. Kegunaan dari media-media tersebut untuk menghindari verbalisme yang masih mungkin terjadi kalau hanya digunakan alat bantu visual semata. Dalam usaha memanfaatkan media sebagai alat bantu, Edgar Dale telah mengklasifikasikan beberapa sumber belajar yang kemudian menjadi pengalaman belajar menurut tingkatannya yaitu dari yang paling kongkrit ke yang paling abstrak. Klasifikasi tersebut dikenal dengan nama krucut pengalaman pembelajaran (learning cone of experience). ${ }^{2}$

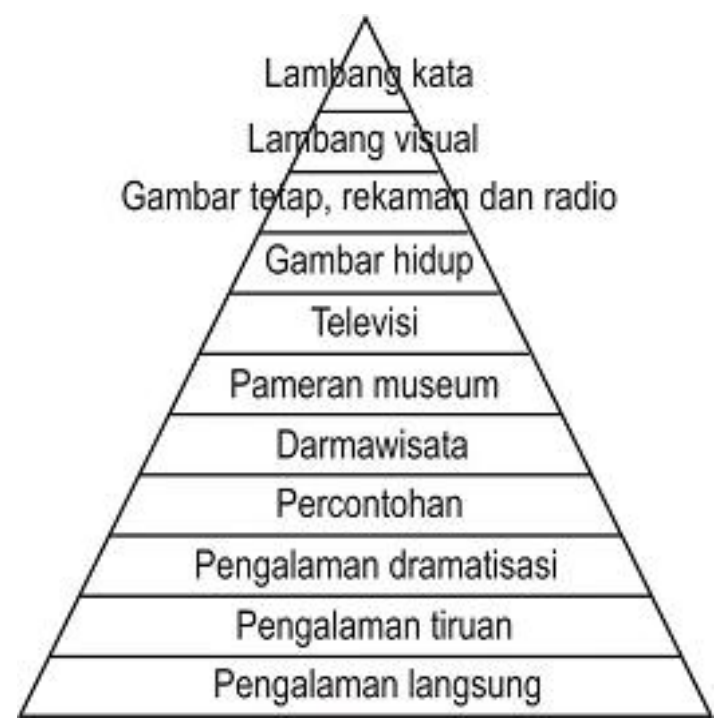

Learning Cone of Experience.

Sumber: Jurnal Pendidikan Penabur - No.04 / Th.IV / Juli 2005

Berdasarkan kerucut pengalaman Edgar Dale di atas, semuanya terdapat pada lingkungan belajar bahasa. Lingkungan ini akan sangat membantu dalam proses pembelajaran baik

2 Thomas Wibowo Agung Sutjiono, Pendayagunaan Media Pembelajaran, (Jurnal Pendidikan Penabur - No.04 / Th.IV / Juli 2005), 79 
Jurnal al-Af'idah: Jurnal Pendidikan bahasa Arab Dan Pengajarannya. Volume I,Nomor I September 2017

yang dituangkan dalam audio visual maupun secara langsung yang nantinya siswa mampu mengobservasi sendiri pada apa yang diamatinnya. Selain itu, mahasiswa memperoleh ilmu dan pengalaman langsung yang dapat diaplikasikan berdasarkan teori ke praktek yang telah dipelajarinya.

Kerucut pengalaman pembelajaran Edgar Dale tersebut merupakan suatu acuan dalam pemilihan media untuk sumber dan sarana belajar bagi mahasiswa dengan tetap mengacu pada karakteristik serta tugas perkembangan mahasiswa sehingga penggunaan dan pemanfaatan media dalam pembelajaran dapat memperoleh hasil optimal. Jadi, media membantu dan mempermudah proses pembelajaran bagi peserta didik bukan sebaliknya yaitu mempersulit proses pembelajaran bagi mahasiswa.

Penulis mencoba untuk menguraikan lingkungan belajar, dalam hal ini lingkungan belajar bahasa sebagai media pembelajaran bahasa Arab. Dan untuk mempermudah pembahasan ini maka penulis merumuskan masalah sebagai berikut;

1. Apa definisi lingkungan belajar berbahasa?

2. Apa Jenis lingkungan belajar berbahasa yang digunakan sebagai media pembelajaran?

3. Apa tujuan lingkungan berbahasa sebagai media pembelajaran?

4. Bagaimana penerapan dan teknik penggunaan lingkungan belajar berbahasa sebagai media pembelajaran bahasa Arab? 
Jurnal al-Af'idah: Jurnal Pendidikan bahasa Arab Dan Pengajarannya. Volume I,Nomor I September 2017

5. Apa kelebihan dan kekurangan lingkungan belajar berbahasa sebagai media pembelajaran bahasa Arab?

\section{B. PEMBAHASAN}

\section{Definisi Lingkungan Belajar Berbahasa}

Istilah lingkungan menurut Kamus besar bahasa Indonesia diartikan sebagai suatu tempat yang memengaruhi tumbuh-kembangnya suatu individu. Dalam kamus bahasa Inggris lingkungan yaitu environment yang memiliki makna sebagai sesuatu yang berhubungan dengan suasana. Jika kedua istilah lingkungan tersebut diintegrasikan, maka lingkungan dapat diartikan sebagai suatu suasana atau keadaan yang dapat memengaruhi pertumbuhan dan perkembangan individu. Secara umum, belajar diartikan sebagai perubahan tingkah laku yang relatif menetap pada diri individu, perubahan dalam belajar bertujuan atau kearah pada perubahan yang mencakup seluruh aspek tingkah laku. ${ }^{3}$

Pada pemahaman yang lain, Istilah lingkungan belajar berbahasa dapat diartikan sebagai suatu proses mengkoordinasi dan mengintegrasikan berbagai komponen lingkungan yang dapat memengaruhi perubahan perilaku bahasa peserta didik. Maka dari itu, kata lingkungan dan belajar secara sederhana dapat dirumuskan pengertian lingkungan belajar yaitu suatu tempat atau suasana yang memengaruhi proses tingkah laku suatu individu atau pembelajar yang berada di lingkungan

3 Slameto, Belajar dan faktor-faktor yang mempengaruhinya ( Jakarta, RenikaCipta, cet-ke 4, 2003),5. 
Jurnal al-Af'idah: Jurnal Pendidikan bahasa Arab Dan Pengajarannya. Volume I,Nomor I September 2017

tersebut. Penjelasan tersebut dapat dipahami bahwa perubahanperubahan yang diakibatkan oleh lingkungan dapat bersifat menetap dan relatif permanen. Semakin kuat pengaruh lingkungan tersebut, maka perubahan yang terjadi pada subjek belajar dapat diprediksikan akan semakin tinggi pula.

Media pembelajaran memiliki peranan penting untuk menunjang pencapaian tujuan pembelajaran dalam pendidikan. Oemar Hamalik dalam teorinya "Kembali ke Alam" mengemukakan bahwa alam berpengaruh terhadap perkembangan peserta didik. Lebih lanjut, Oemar Hamalik mengeksplorasikan bahwa lingkungan (environment) sebagai faktor dasar penting untuk pengajaran yang kondisional dan mampu memengaruhi tingkah laku suatu individu dan merupakan faktor belajar yang penting. ${ }^{4}$

Maka, lingkungan kehidupan dapat dijadikan sebagai sumber belajar seperti lingkungan masyarakat di sekitar Sekolah yang mencakup bangunan Sekolah, bahan-bahan yang tersisa atau tidak dipakai, dan bahan-bahan bekas. Bendabenda tersebut apabila diolah sebaik mungkin dapat dimanfaatkan sebagai sumber atau alat bantu belajar. Lingkungan yang tidak hanya bersifat wujud tapi juga berupa peristiwa alam dan peristiwa yang terjadi dalam masyarakat. Kondisi-kondisi yang alami yang terjadi itu dapat pula sebagai sumber bahan belajar. Jadi, media pembelajaran lingkungan adalah pemahaman terhadap gejala atau tingkah laku tertentu

${ }^{4}$ Oemar Hamalik, Media Pendidikan. ( Bandung: Penerbit PT. Citra Aditya Bakti, 1994.), 195. 
Jurnal al-Af'idah: Jurnal Pendidikan bahasa Arab Dan Pengajarannya. Volume I,Nomor I September 2017

dari objek atau pengamatan ilmiah terhadap sesuatu yang ada di sekitar sebagai bahan pengajaran. Keadaan ini terjadi pada peserta didik sebelum dan sesudah menerima materi pelajaran dari sekolah dengan membawa pengalaman dan penemuan dengan apa yang telah ditemui di lingkungan yang merupakan tempat sosialnya.

\section{Jenis Lingkungan Pembelajaran Bahasa}

Dalam proses pembelajaran bahasa ada dua hal yang sangat terkenal yaitu pemerolehan bahasa (language acquisition) dan pembelajaran bahasa (Language learning). Pemerolehan bahasa (language acquisition) adalah proses penguasaan bahasa kedua secara alami melalui alam bawah sadar dengan cara berkomunikasi langsung dengan orang-orang yang menggunakan bahasa tersebut. Kemudian, pembelajaran bahasa (language learning) adalah proses penguasaan bahasa secara sadar terutama tentang kaidah-kaidah bahasa dengan cara diajarkan baik oleh seorang guru maupun belajar secara mandiri. ${ }^{5}$

Berdasarkan istilah Language Acquisition dan Language Learning, menurut Krashen dalam "Metodologi Pengajaran Bahasa Arab" yang dirilis oleh Efendi. bahwa lingkungan pembelajaran bahasa terbagi menjadi dua yaitu sebagi berikut: ${ }^{6}$

\footnotetext{
${ }^{5}$ Ahmad Fuad Efendi, Metodologi Pengajaran Bahasa Arab, (Malang: Misykat Malang), 221

${ }^{6}$ Efendi, Metodologi ......., 223
} 
Jurnal al-Af'idah: Jurnal Pendidikan bahasa Arab Dan Pengajarannya. Volume I,Nomor I September 2017

a) Lingkungan Belajar Bahasa Arab yang Bersifat Formal

Lingkungan formal adalah salah satu lingkungan belajar yang memfokuskan pada penguasaan secara sadar terhadap kaidah atau aturan bahasa target. Artinya,lingkungan formal merupakan lingkungan atau tempat berlangsungnya proses pembelajaran. Pada umumnya di Indonesia proses pembelajaran berlangsung di dalam kelas. ${ }^{7}$

Ciri-ciri lingkungan bahasa yang bersifat formal adalah sebagi berikut:

1. Bersifat artifisial

2. Pembelajar bahasa diarahkan untuk melakukan aktifitas bahasa yang menampilkan kaidah-kaidah bahasa yang telah dipelajari.

3. Pendidik memberikan umpan-balik yang berupa mengkoreksi kesalahan peserta didik.

4. Merupakan bagian dari keseluruhan pembelajaran di Sekolah.

b) Lingkungan BelajarBahasa yang Bersifat Informal.

Lingkungan yang fokus pada proses penguasaan bahasa secara alami melalui pikiran bawah sadar dengan cara berkomunikasi langsung dengan orang-orang yang menggunakan bahasa tersebut. Bahasa pada lingkungan informal seperti bahasa yang digunakan kawan-kawan sebaya, bahasa pengasuh atau orang tua, bahasa yang digunakan anggota kelompok atau etnis pembelajar, bahasa yang

${ }^{7}$ Suwarana Pringgawidagda, Strategi Penguasaan Bahasa,( yogyakarta : Adicita Karya Nusa, 2002), 34 
Jurnal al-Af'idah: Jurnal Pendidikan bahasa Arab Dan Pengajarannya. Volume I,Nomor I September 2017

digunakan media massa, bahasa para guru baik di kelas maupun di luar kelas. Maka, secara umum dapat dikatakan bahwa lingkungan ini sangat berpengaruh terhadap hasil belajar bahasa kedua para pembelajar.

Adapun karakteristik lingkungan belajar bahasa bersifat informal menurut Tarigan, dkk adalah sebagai berikut

a) Berlangsung dalam situasi alami seperti pada anak-anak yang belajar bahasa tanpa beban, dan diluar Sekolah.

b) Dialami langsung oleh anak dan terjadi dalam konteks berbahasa yang bermakna bagi anak.

c) Pemilikan bahasa tidak melalui pembelajaran formal seperti di lembaga-lembaga pendidikan.

d) Dilakukan tanpa sadar atau secara spontan. ${ }^{8}$

\section{Tujuan Lingkungan Belajar Berbahasa Sebagai Media Pembelajaran Bahasa Arab}

Menurut Wragg bahwa upaya menata lingkungan belajar bahasa dimaksudkan agar lingkungan ada mampu menstimulasi anak-anak berpartisipasi dalam kegiatan belajar terutama berbahasa secara optimal sehingga tujuan belajar dapat tercapai sesuai dengan yang diharapkan. ${ }^{9}$ Rianto mengungkapkan bahwa menata lingkungan belajar merupakan upaya pendidik untuk menciptakan dan mengendalikan kondisi pembelajaran serta memulihkannya apabila terjadi gangguan atau penyimpangan sehingga proses

\footnotetext{
${ }^{8}$ Henry Guntur Tarigan dkk. Pengajaran Pemerolehan Bahasa
} (Bandung:Angkasa, ISBN: 97897940438821988), 26. 
Jurnal al-Af'idah: Jurnal Pendidikan bahasa Arab Dan Pengajarannya. Volume I,Nomor I September 2017

pembelajaran dapat berlangsung secara optimal. Optimalisasi proses pembelajaran akan terlihat pada keterlaksanaan serangkaian kegiatan pembelajaran (instructional activities) yang sengaja direkayasa oleh pendidik sehingga dapat berlangsung secara efektif dan efisien dalam mengantar peserta didik yang pada akhirnya dapat meraih hasil belajar sesuai harapan. ${ }^{9}$

Berbagai macam bentuk interaksi atau komunikasi dengan menggunakan bahasa tertentu yang terbangun memberikan kemudahan bagi peserta didik untuk memperoleh pengalaman belajar berbahasa (language learning experiences) dalam rangka menumbuh-kembangkan kemampuannya (kompetensi) berbahasa. Oleh karena itu, dapat ditegaskan lebih lanjut bahwa secara fisik lingkungan belajar berbahasa harus menarik dan mampu membangkitkan gairah belajar berbahasa serta menghadirkan suasana yang nyaman untuk belajar seperti kelas belajar harus bersih, tempat duduk ditata sedemikian rupa agar peserta didik bisa melakukan aktivitas belajar secara bebas. Pemanfaatan lingkungan berbahasa sebagai sumber belajar berbahasa adalah untuk mengupayakan terjadinya proses komunikasi secara alami antar para siswa dan masyarakat yang ada disekitar siswa. Jadi, Tujuan dari pemanfaatan lingkungan berbahasa adalah untuk menghasilkan bahasa atau kompetensi bahasa yang sesuai dengan harapan.

${ }^{9}$ Rita Mariyana, dkk, Pengelolaan Lingkungan Belajar, 18. 
Jurnal al-Af'idah: Jurnal Pendidikan bahasa Arab Dan Pengajarannya. Volume I,Nomor I September 2017

4. Penerapan dan Teknik Penggunaan Lingkungan Belajar Berbahasa sebagai Media Pembelajaran Bahasa Arab.

Jika lingkugan belajar bahasa diibaratkan sebagai laboratorium dan merupakan tempat peserta didik berkembang dan belajar, maka laboratorium tersebut harus mampu mendorong, mampu menjadi sumber inspirasi, menjadi tempat penemuan, menjadi tempat melatih untuk pemecahan masalah kebahasaan, menjadi tempat pengembangan diri kualitas kebahasaan anak, menjadi tempat penyaluran segala ekspresi kebahasaan, dan sebagainya. Konsekuensinya, para pendidik bahasa Arab harus semangat menyiapkan lingkungan belajar yang memiliki berbagai kemampuan tersebut.

Untuk dapat mewujudkan lingkungan belajar bahasa yang sesuai dengan harapan, maka lingkungan tersebut perlu dikembangkan pada prinsip-prinsip berikut ini: ${ }^{10}$

a. Prinsi Merefleksikan Selera Peserta Didik

Lingkungan belajar bahasa Arab harus menarik bagi peserta didik. Maka dalam penyediaan dan pengemasan lingkungan belajar tersebut harus dipertimbangkan karakteristik, perasaan, minat, dan dinamika belajar peserta didik. Artinya, lingkungan belajar bahasa Arab yang diciptakan perlu diselaraskan dengan tahapan-tahapan perkembangan dan cara-cara khas belajar peserta didik.

${ }^{10}$ RitaMariyana, dkk, Pengelolaan Lingkungan, 25. 
Jurnal al-Af'idah: Jurnal Pendidikan bahasa Arab Dan Pengajarannya. Volume I,Nomor I September 2017

b. Prinsip Optimalisasi Perkembangan dan Belajar Anak

Prinsip ini mengandung arti bahwa perkembangan dan hasil belajar yang diharapkan dapat tercapai apabila kegiatan belajar bahasa berorientasi pada kondisi dan cara belajar serta kebutuhan bahasa peserta didik.

Penekanan prinsip adalah sebagai berikut:

1) Mengembangkan seluruh dimensi perkembangan anak secara holistik.

2) Mengalihkan aktivitas belajar bahasa anak sesaat ke belajar sepanjang hayat

3) Membantu anak belajar bukan hanya mengingat segala pengalaman belajarnya sesaat, tetapi juga dapat memberikan lompatan memori yaitu dari ingatan jangka pendek ke ingatan jangka panjang.

4) Menciptakan aktivitas yang bernuansa menyenangkan, nyaman, aman dan lebih alami.

5) Mengarahkan pengorganisasian pesan-pesan pembelajaran, baik secara kognitif, afektif maupun psikomotorik.

c. Prinsi Berpijak pada Efisiensi Pembelajaran.

Prinsip ini bahwa kegiatan pembelajaran dilakukan secara produktif dan tepat guna mengingat waktu, energi, maupun upaya yang akan dilakukan.

\subsection{Lingkungan Bahasa Arab Formal}

Supaya lingkungan bahasa Arab yang bersifat formal berfungsi sebagai media yang mampu memberikan 
Jurnal al-Af'idah: Jurnal Pendidikan bahasa Arab Dan Pengajarannya. Volume I,Nomor I September 2017

pemerolehan bahasa peserta didik, dalam hal ini keterampilan berbahasa tidak hanya pengetahuan bahasa, maka kegiatan pembelajaran di kelas hendaknya menerapkan gabungan pendekatan komunikatif, quantum, dan kontekstual.

Untuk memperjelas keadaan pemahaman, maka lingkungan bahasa Arab formal ketika interaksi pembelajaran adalah sebagi berikut:

a. Menggunakan strategi interaksionis yang bertumpu pada kegiatan-kegiatan komunikatif bukan drill-drill mekanistik-manipulatif.

b. Menggunakan materi yang bervariasi dengan memperbanyak bahan-bahan otentik yang memperhatikan prinsip-prinsip kebermaknaan, kegunaan, dan kemenarikan.

c. Memperluas input kebahasaan bagi para siswa dengan acara memberikan tugas seperti membaca buku, majalah, dan koran berbahasa Arab, mendengar siaran radio dan memperhatikan siaran televisi yang berbahasa Arab.

d. Mengarahkan dan memfasilitasi peserta didik untuk intens berkomunikasi.

e. Dianjurkan lebih menggunakan bahasa Arab meskipun penggunaan bahasa Indonesia dalam keadaan tertentu tidak ditabukan.

f. Menggunakan metode yang relevan dan teknik-teknik yang bervariasi. 
Jurnal al-Af'idah: Jurnal Pendidikan bahasa Arab Dan Pengajarannya. Volume I,Nomor I September 2017

g. Merancang dan menyelenggarakan berbagai kegiatan penunjang seperti latihan menulis insya' (kegiatan harian), latihan pidato, dan sejenisnya. ${ }^{11}$

Agar lingkungan formal dapat menjadi media yang memberi masukan pemerolehan wacana bahasa dan bukan sekadar sistem bahasa, maka pendidik dan peserta didik harus bekerja sama untuk memanfaatkan media yang ada dalam ruang kelas. Pada kondisi ini pendidik ditekankan untuk merancang sumber daya yang ada dalam kelas untuk dijadikan media dalam memperkaya wacana peserta didik. Untuk itu perlu ada klasifikasi sumber yang ada di dalam kelas. Lazimnya, sebuah kelas terdapat benda-benda berikut: 1). Papan tulis dan perlengkapannya, 2). Papan absensi, 3). Daftar hadir, 4). Jurnal guru, 5) lemari buku dengan buku-buku atau majalah, 6). Bendera, 7). Taman kelas, 8). Denah kelas atau jadwal kebersihan kelas, 9). Gambar-gambar peraga (termasuk peta), 10). Lauhat al ibtikar (papan kreasi siswa), 11). Gambargambar pahlawan, 12). Kalender akademik dan almanak, 13). Perangkat pengeras suara (ampliflaier dan tape recorder), 14). Perangkat komputer dan LCD proyektor (untuk kelas multi media) dan lain-lain.

Oleh karena itu, keberadaan sarana yang ada dalam kelas harus dimanfaatkan sebaik mungkin seperti sebagai media belajar untuk mengoptimalkan proses pembelajaran dan mengaktifkan belajar peserta didik. Apapun bentuk dan rupa

${ }^{11}$ Ahmad Fuad Efendi, Metodologi, 226 
Jurnal al-Af'idah: Jurnal Pendidikan bahasa Arab Dan Pengajarannya. Volume I,Nomor I September 2017

benda yang ada dalam ruang kelas, dapat dijadikan sumber dan pengalaman belajar.

Selain itu, terdapat beberapa hal yang dapat dilakukan untuk mengoptimalkan sumber belajar dan dan menciptakan pengalaman belajar sesuai dengan keadaaa lingkungan belajar. Hal tersebut adalah sebagi berikut:

1. Untuk mengoptimalkan papan tulis sebagai media untuk membentuk kebiasaan berbahasa (bi'ah lughawiyah) yaitu dengan cara selalu menuliskan kalender hijriyah atau masehi dengan bahasa Arab seperti tanggal, bulan, dan tahun pada pojok kiri atas papan tulis. Pada bagian kanan atas selalu dituliskan maddah, (materi) maudhu' (tema) dan mabhats (pembahasan) atau halaman dari buku yang akan dibahas. Pada bagian tengah papan tulis selalu ditulis kalimat basmalah.

Kemudian, agar keterangan tertulis pada papan tulis tidak membingungkan peserta didik, papan tulis dibagi menjadi beberapa bagian dengan garis vertical. Misalnya papan tulis dijadikan tiga bagian. Pada bagian pertama berisi mufradat atau kosa kata, bagian kedua berisi qawai'd atau tata bahasa bagian ketiga kita gunakan untuk latihan dan gambar-gambar penjelas. Apabila memang diperlukan, penggunaan kapur atau spidol berwarna sangat dianjurkan.

2. Papan absensi siswa hendaknya selalu ditulis dengan bahasa Arab atau dengan menggunakan dua bahasa yaitu Arab dan lainnya, kalau memungkinkan daftar 
Jurnal al-Af'idah: Jurnal Pendidikan bahasa Arab Dan Pengajarannya. Volume I,Nomor I September 2017

absensi siswa ditulis dengan bahasa Arab. Akan tetapi kalau tidak memungkinkan, maka hendaknya guru bahasa Arab mempunyai absen khusus yang ditulis dengan bahasa Arab. Kemudian, hendaknya peserta didik yang membaca dan melakukan panggilan absen untuk kawan-kawannya sehingga peserta didik akan terbiasa membaca format absensi dalam bahasa Arab.

3. Jurnal guru hendaknya juga dibuat dengan format berbahasa Arab. Tetapi kalau tidak memungkinkan dilakukan untuk semua pelajaran, maka guru bahasa Arab hendaknya memiliki jurnal khusus dengan format bahasa Arab. Peserta didik diminta untuk mengisi sesuai dengan arahan pendidik sehingga peserta didik terbiasa melihat dan mengisi blanko berbahasa Arab.

4. Lemari yang ada di dalam kelas hendaknya tidak hanya berisi buku-buku pelajaran atau referensi yang berbahasa Indonesia atau Inggris saja, tetapi juga harus diisi dengan buku-buku, majalah, koran atau kemasankemasan barang yang berbahasa. Untuk mendapatkan koran-koran atau majalah yang berbahasa Arab ini dapat dilakukan dengan berlangganan atau dengan meminta dari kantor-kantor kedutaan negara-negara Arab. Sumber-sumber media ini pada saat-saat tertentu dapat dijadikan sebagai bahan diskusi atau materi pelajaran bahasa Arab.

5. Kelas yang di-setting tidak seperti mobil dan monotone seperti yang lazimnya ada. Akan tetapi, ditata dalam 
Jurnal al-Af'idah: Jurnal Pendidikan bahasa Arab Dan Pengajarannya. Volume I,Nomor I September 2017

bentuk yang lain sehingga memudahkan pendidik mengenali peserta didiknya dan peserta didik melihat temanya.

6. Adapun gambar peraga atau peta, hendaknya guru memberi tugas kepada siswa untuk membuatnya sendiri dengan memberi label pada peta atau gambar gambarnya dengan bahasa Arab. Gambar peraga yang dibuat hendaknya gambar yang sederhana dan tidak terlalu menyertakan detail-detail yang tidak perlu, agar memudahkan penjelasan apabila diperlukan.

7. Hal yang paling menarik adalah hendaknya di setiap kelas disediakan papan majalah dinding berukuran 150 $\mathrm{cm}$ x $120 \mathrm{~cm}$ yang digunakan sebagai papan untuk menempelkan hasil karya siswa yang bernuansa bahasa. Contoh karya peserta didik dapat berupa cerita pendek, cerita bergambar, teka teki, usulan perbaikan untuk guru atau kelas, dan apa saja yang ingin ditulis atau digambar oleh peserta didik.

8. Kalender akademik hendaknya juga dibuat dengan bahasa Arab. Apabila tidak memungkinkan, maka dapat dibuat dengan dua format yaitu Arab dan lainnya, sedang almanak atau penanggalan dipilih penanggalan Arab. Penulisan kalender akademik dengan dua bahasa biasanya justru akan memecah konsentrasi siswa, maka akan lebih bagus apabila hanya dengan format Arab saja. Alasanya, peserta didik cenderung hanya akan membaca yang berbahasa Indonesia karena lebih mudah 
Jurnal al-Af'idah: Jurnal Pendidikan bahasa Arab Dan Pengajarannya. Volume I,Nomor I September 2017

dimengerti. Konsekuensinya, tujuan kebiasaan berbahasa (bi'ah lughawiyah) tidak tercapai.

9. Pada dinding kelas hendaknya juga ditempeli hasil karya siswa yang bernuansa Arab seperti: tulisan kaligrafi, lukisan suasana timur tengah, ornamenornamen Arab dan lain-lain.

10. Apabila terdapat perangkat pengeras suara dan tape recorder di dalam kelas, maka harus dilengkapi dengan kaset-kaset berbahasa Arab dan kalau bisa yang berisi rekaman dari native speaker, baik berupa pidato, percakapan (hiwar), lagu (nasyid) atau lainnya. Kasetkaset yang berbahasa Arab saat ini tidak sulit didapatkan karena sudah ada ditoko-toko buku atau di lembagalembaga dakwah. Pendidik juga dapat mempersiapkan bahan ini dengan merekam siaran radio berbahasa Arab lewat gelombang SW atau televisi bersatelit parabola (kalau ada), atau situs internet berbahasa Arab baik berupa berita, wawancara, film, ceramah, atau apa saja, kemudian diperdengarkan dikelas dan dianalisis seksama.

Cara-cara yang telah dipaparkan sebelumnya diatas dapat dijadikan acuan untuk meningkatkan kualitas pembelajaran dan belajar bahasa arab. Disamping itu, dapat menjadi sumber untuk menumbuhkembangkan $b i$ 'ah lughawiyah peserta didik. Singkatnya, keberadaan suatu benda dapat dijadikan media untuk membentuk bi'ah yang baik. Akan tetapi, peran guru dan kebijakan lembaga serta 
Jurnal al-Af'idah: Jurnal Pendidikan bahasa Arab Dan Pengajarannya. Volume I,Nomor I September 2017

kerja sama dengan peserta didik memiliki peran yang cukup signifikan untuk membuat usaha ini berhasil.

\subsection{Lingkungan Bahasa Arab informal}

Lingkungan belajar bahasa Arab yang bersifat informal yang sesungguhnya bagi pembelajar bahasa Arab di Indonesia adalah negeri Arab itu sendiri, karena di Indonesia tidak ditemukannya lingkungan seperti di Negara Arab. Maka dari itu, perlu diciptakan lingkungan yang mendekati lingkungan Arab yang sesungguhnya.

Untuk memecahkan kondisi harapan itu, terdapat strategi-strategi yang dapat dilakukan seperti yang dikemukakan oleh Fuad Effendi sebagai berikut:

a. Sumber daya Manusia

Adanya SDM yang memiliki kompetensi komunikatif bahasa Arab baik lisan maupun tulis, SDM yang handal akan menjadi model sekaligus penggerak aktifitas kebahasa araban.

b. Lingkungan Psikologis

Dalam hal ini dimulai membentuk citra positif bahasa Arab di mata warga madrasah terutama peserta didik. Langkah-langkah yang dapat dilakukan adalah;Pertama, memberikan penjelasan kepada peserta didik secara objektif dan realistis tentang bahasa Arab. Kedua, menjelaskan kepada peserta didik manfaat kemampuan berbahasa Arab bagi yang memilikinya dalam kehidupan pribadi dan social. 
Jurnal al-Af'idah: Jurnal Pendidikan bahasa Arab Dan Pengajarannya. Volume I,Nomor I September 2017

Ketiga,menampilkan pengajaran bahasa Arab sedemikian rupa sehingga membentuk citra pelajaran bahasa Arab sebagai bahasa yang menyenangkan, mudah, dan bermanfaat.

c. Lingkugan Bicara

Menciptakan lingkungan yang menggunakan bahasa Arab dalam interaksi sehari-hari secara bertahap.

d. Lingkungan Dengar

Lingkungan ini bisa dilakukan dengan menyampaikan informasi secara lisan dalam bahasa Arab.

e. Lingkungan Pandang-Baca

Menciptakan lingkungan ini relatif lebih mudah dan apabila dirancang dengan baik, maka dapat memberikan efek yang cukup kuat bagi pemerolehan bahasa siswa.

f. Lingkungan Pandang-Dengar

Lingkungan ini bisa diciptakan dengan memanfaatkan teknologi informasi. Misalnya menampilkan tayangan telivisi yang siarannya berbahasa Arab.

g. Kelompok Pecinta Bahasa Arab

Membentuk kelompok-kelompok pecinta bahasa Arab dengan berbagai aktivitas yang bernuansa Arab. 
Jurnal al-Af'idah: Jurnal Pendidikan bahasa Arab Dan Pengajarannya. Volume I,Nomor I September 2017

h. Penyelenggaraan Pekan Arabi

Membuat suatu kegiatan yang beraneka ragam tapi semuanya bernuansa bahasa Arab. Contohnya; lomba pidato, menulis, lomba kaligrafi, dan lainlain.

i. Self Access Centre

Tempat pusat pembelajaran bahasa Arab yang menyediakan berbagai macam fasilitas yang menunjang kegiatan belajar bahasa Arab. Self Acces Centre (SAC) adalah pusat untuk mengakses. ${ }^{12}$

\section{Keuntungan dan Kelemahan Media Lingkungan Belajar}

\section{Bahasa Arab}

\subsection{Keuntungan Media Lingkungan Belajar Arab}

Adanya pemanfaatan lingkungan sebagai media pembelajaran lebih bermakna disebabkan oleh peserta didik berhadapan langsung dengan peristiwa dan keadaan yang sebenarnya secara alami. Akibatnya, kegiatan pembelajaran bahasa Arab lebih nyata, lebih faktual, dan kebenarannya dapat dipertanggung jawabkan.

Banyak keuntungan yang dapat diperoleh dari penggunaan lingkungan sebagai media pembelajaran bahasa seperti sebagai berikut:

a. Kegiatan belajar lebih menarik dan tidak membosankan sehingga motivasi belajar peserta didik akan lebih tinggi.

\footnotetext{
${ }^{12}$ Ahmad Fuad Efendi, Metodologi, hlm 226
} 
Jurnal al-Af'idah: Jurnal Pendidikan bahasa Arab Dan Pengajarannya. Volume I,Nomor I September 2017

b. Hakikat belajar akan lebih bermakna sebab peserta didik dihadapkan langsung dengan situasi dan keadaan yang sebenarnya atau alamiah.

c. Bahan-bahan yang dapat dipelajari lebih kaya serta lebih faktual sehingga kebenarannya lebih akurat.

d. Kegiatan belajar lebih komprehensif dan lebih aktif sebab dapat dilakukan dengan berbagai cara seperti mengamati, bertanya, atau wawancara, membuktikan atau mendemonstrasikan, dan menguji fakta.

e. Sumber belajar menjadi lebih kaya sebab lingkungan yang dapat dipelajari sangat beraneka ragam.

f. Siswa juga lebih dapat memahami dan menghayati aspekaspek kehidupan yang ada dilingkungannya. Akibatnya, dapat membentuk pribadi yang tidak asing dengan kehidupan di sekitarnya, serta dapat memupuk rasa cinta akan lingkungan.

\subsection{Kelemahan Media Lingkungan Belajar Arab}

1. Keterbatasan dari lingkungann bahasa yang disadari oleh kebanyakan para pembelajar adalah bahwa pengetahuan bahasa tidak selalu menjamin peserta didik untuk mampu menggunakannya dalam situasi komunikasi yang sebenarnya. Hanya saja sebagian pelajar merasa lebih nyaman menggunakan bahasa dalam berkomunikasi ketika peserta didik mengetahui dan sadar akan aturanaturan tata bahasa. 
Jurnal al-Af'idah: Jurnal Pendidikan bahasa Arab Dan Pengajarannya. Volume I,Nomor I September 2017

2. Tidak adanya sikap positif terhadap bahasa Arab dan komitmen bersama yang kuat disebagian lembaga pendidikan untuk memajukan pengajaran bahasa Arab dengan membentuk lingkungan berbahasa Arab oleh pihak-pihak terkait yaitu pendidik bahasa Arab itu sendiri dan pimpinan lembaga.

3. Untuk menghasilkan peserta didik yang mampu berbahasa secara maksimal, proses penggunaanya memerlukan waktu yang relatif lama.

\section{PENUTUP}

Dari pemaparan yang telah diuraikan secara singkat, maka dapat disimpulkan bahwa: Lingkungan belajar berbahasa diartikan sebagai suatu proses mengkondisikan dan mengintegrasikan berbagai komponen lingkungan yang dapat memengaruhi perubahan perilaku peserta didik dalam hal ini berbahasa Arab sehingga terfasilitasi secara baik. Ditinjau dari segi jenisnya Lingkungan pembelajaran bahasa terbagi menjadi dua yaitu lingkungan belajar bahasa Arab yang bersifat formal dan informal. Lingkungan belajar bahasa Arab yang bersifat formal yaitu salah satu lingkungan belajar yang memfokuskan pada penguasaan secara sadar terhadap kaidah atau aturan bahasa target. Lingkungan belajar bahasa bersifat informal yaitu lingkungan yang fokus pada proses penguasaan bahasa secara alamiah melalui alam pikir bawah sadar dengan cara berkomunikasi langsung dengan orang-orang yang menggunakan bahasa tersebut. 
Jurnal al-Af'idah: Jurnal Pendidikan bahasa Arab Dan Pengajarannya. Volume I,Nomor I September 2017

Tujuan pemanfaatan lingkungan berbahasa sebagai sumber belajar berbahasa adalah untuk mengupayakan agar terjadi proses komunikasi berbahasa secara alami antar para peserta didik dan masyarakat yang ada disekitarnya. 
Jurnal al-Af'idah: Jurnal Pendidikan bahasa Arab Dan Pengajarannya. Volume I,Nomor I September 2017

\section{DAFTAR PUSTAKA}

Agung Sutjiono, Thomas Wibowo, Pendayagunaan Media Pembelajaran, Jurnal Pendidikan Penabur - No.04 / Th.IV / Juli 2005.

Fuad Efendi, Ahmad. Metodologi Pengajaran Bahasa Arab,Malang: Misykat Malang.

Hamalik, Oemar, Media Pendidikan. Bandung : Penerbit PT. Citra Aditya Bakti, 1994.

Mariyana, Rita dkk, Pengelolaan Lingkungan Belajar,Jakarta,Kencana Prenada Media Group, 2010.

Nurseto, Tejo, Membuat Media Pembelajaran yang Menarik,UNY, Jurnal Ekonomi \& Pendidikan, Volume 8 Nomor 1, April 2011.

Pringgawidagda, Suwarana. Strategi Penguasaan Bahasa, yogyakarta : Adicita Karya Nusa, 2002.

Slameto, Belajar dan faktor-faktor yang memengaruhinya, Jakarta, Renika Cipta, cet-ke 4, 2003.

Tarigan dkk , Henry Guntur. Pengajaran Pemerolehan Bahasa. Bandung: Angkasa, ISBN: 9789794043882, 1988 